\title{
FIELD PERFORMANCE AND PHYSIOLOGICAL GROWTH OF FOUR HYBRIDS DERIVED FROM THE SIXTH GENERATION OF DURUM WHEAT
}

Ismail Hussain Ali

College of Agriculture/Universsity of Salahaddin

E-mail:dr.ismail@ymail.com

\begin{abstract}
This study was carried out in the field of College of Agriculture - University of Salahaddin in Erbil during the season 2009 - 2010 including the evaluation of four hybrids derived from diallel crosses among seven varieties of durum wheat, previously assessed on the basis of combining ability and heterosis of them. The breeding program continued until these hybrids reached the sixth generation, and were compared with three other varieties, two of them cultivated on a large scale. Fifteen traits were studied, including different growth, physiological characters and grain yield and its components. The hybrid (Acsad- $65 \times$ Kosem- N) has been selected to continue its breeding in order to adopt a new variety based on its performance superior in most of the studied traits, especially in the productivity score and grain yield and in traits that are showed positive correlation with the grain yield like leaf area index, net assimilation rate, spike length, 1000-grain weight and spikes $/ \mathrm{m}^{2}$, which had the greatest effect in the prediction of grain yield according to the results of multiple regression analysis.

Keywords: Durum wheat, Field performance, Physiological growth.
\end{abstract}

Received 29/3/2011 accepted 2/1/2012.

\section{INTRODUCTION}

Durum wheat (Triticum durum Desf.) is usually grown under rain fed conditions in the Mediterranean region where drought and heat stress constrain yield potential during the grain filling period (Simane et al., 1993). (Spitters and Kramer, 1986) found that the differences in the growth of genotypes contribute to the understanding of differences competitive between varieties of wheat and benefit plant breeders of these differences in the selection which are the most important characters are leaf area index, relative growth rate, net assimilation rate, the movement of dry matter from the source (leaves) to downstream (grain) and flag leaf area and different varieties of wheat in the yield according to the different in these qualities and field characters such as the yield components. The differences between wheat varieties was stated by (Watson et al., 1963 and Langer, 1967) that leaf area index, especially after the flowering stage, is the most important specific characteristics of grain yield in cereals. Campbell et al. (1969), Abd-El-Gawad et al. (1985), Al- Rawi and Faisal (1995) and Aslam Khan et al. (2005) found difference between the varieties of wheat in the relative growth rate, net assimilation rate and representatives of the transition of dry matter to grains and their contribution to excellence in yield. 
Grain yield can be expressed as the result of three physiological processes: radiation interception by photosynthetic organs, conversion of the intercepted radiation into dry matter and partitioning of that dry matter, as expressed by harvest index (Hay and Walker, 1989). The first process is related to the photosynthetic area and, therefore, to leaf area index; the second one is related to photosynthetic efficiency. Total biomass or biological yield is the result of these two processes. Harvest index is the ratio of grain yield to biological yield.

Significant relationship between yield and biomass at anthesis or during grain filling have been reported in bread wheat (Turner, 1997), and durum wheat (Villegas et al., 2001). In small grain cereals biomass or leaf area in early developmental stages has also been positively related to grain yield under Mediterranean-type environments, due to the reduction of soil water losses from evaporation and the increase in water use efficiency (Hafid et al., 1998). Water stress may affect the growth of wheat, but the effects are small when stress occurs in the early stages than when it occurs in the late vegetative phase and during grain filling (Abayomi and Wright, 1999). Both dry weight per plant and total aboveground biomass are affected by drought as consequence of a decrease in the rate of growth (Villegas et al., 2001).

Based on the foregoing and because of need to increase the sources of genetic variability and to produce new varieties of durum wheat, this study aims to evaluate the four hybrids derived in the sixth generation, and compared with three other varieties through the study of some of the characteristics of field and physiological relevant direct relationship with grain yield of wheat in order to determine the genetic makeup that would be created in the seventh generation to be selected plants individually and then grown in lines individually and evaluated in subsequent generations to reach in the end to new variety.

\section{MATERIALS AND METHODS}

This study was carried out in the field of the College of Agriculture, University of Salahaddin during the season 2009-2010 under rainfall conditions $(315 \mathrm{~mm})$ with good distribution registered by meteorological station at the site of the study. Four hybrids in the sixth generation resulting from diallel crosses between seven varieties of durum wheat (Table, 1), which selecting depended on the heterosis, values of selection indices and the measure of productivity scores (Ali, 2006), allowed the continuation of these superior hybrids until the sixth generation, and by following the Bulk-population method of selection according to the steps of the mentioned process by Poehlman and Steper (1994).

Grains of the four hybrids with the three varieties (checks), two of them planted on a large scale in Iraqi Kurdistan region (Acsad- 65, Cham- 3) and (Kosem- N) was obtained from the office of the FAO in Dohuk in 1999 and has demonstrated high efficiency in drought tolerance (Ali and Ismail, 2004). These genotypes were planted on 10/11/2009 under rainfall conditions in a Randomized Complete Block Design with three replications. The experimental plot comprised of four rows of 2.5 meter length, with $20 \mathrm{~cm}$ width in each replication using $140 \mathrm{~kg} /$ ha seeding rate, and then 
irrigated directly to ensure homogeneity of germination and to avoid insect damage. During the period of plant growth to maturity, fifteen traits were studied including various characteristics of growth and physiological characteristics and the yield and its components for the purpose of briefing the full efficiency of the genotypic superior. When the plants arrive to the stage of elongation $50 \mathrm{~cm}$ distance were harvested from a lines of moderation in all experimental unit at the nearest distance from the surface of the soil and calculated leaf area using the equation (leaf length $x$ width $\times 0.95)$, (Thomas, 1975) an average of ten leaves and then multiplied by the number of total leaves exclusion of the lower dry leaves, then dried in an oven electric models on the temperature of $70^{\circ} \mathrm{C}$ for 48 hours to calculate the dry weight.

Table (1): Source and pedigree of durum wheat varieties used as parents in diallel crosses (Ali, 2006).

\begin{tabular}{|c|c|l|c|}
\hline & Variety & \multicolumn{1}{|c|}{ Pedigree } & Source \\
\hline 1 & Senator- capelli & var.leucomelan AL. & ITALY \\
\hline 2 & Cham- 3 & Korifla (DS15/Geier) & ICARDA \\
\hline 3 & Acsad- 65 & STORK CM470-1M-2Y-CM × GDAV2 469-AA'S" & ICARDA \\
\hline 4 & Kosem- N & Obtained from the office of the FAO in Dohuk in 1999 & FAO \\
\hline 5 & Wahat al- Iraq & PIC 'S' Ruff 'S' / RH / GTO & ICARDA \\
\hline 6 & Om- rabi 5 & $\begin{array}{l}\text { Ossl-1/Gdfl.ICD92-0940-CABL-OAP-5AP- } \\
\text { TR.DABOON.Msbl-1/4/Quadalete//Erp/Mal/3/Unk. }\end{array}$ & IRAQ \\
\hline 7 & Cochreat C- 71 & Rasbeenegro eqwelass tehwakan × stewart 63 S & ITALY \\
\hline
\end{tabular}

When plants reached the flowering stage, the following measurements were calculated:

\section{- Leaf Area Index (LAI):}

- Relative Growth Rate (RGR) (g / g / day): formula mentioned by Garretson and Keuls (1986). $R G R=\frac{\operatorname{LnW} 2-\operatorname{Ln} W 1}{d t}$

- Net Assimilation Rate (NAR) (mg / $\mathbf{c m}^{2} /$ day): has been the application of the following equation mentioned by Hunt (1982). NAR $=\frac{(W 2-W 2)(\operatorname{LnA} 2-L n A 1)}{(A 2-A 1) d t}$

- Dry Matter Translocation (DMT) (kg / ha): were calculated in applying the following formula mentioned by Papakosta and Gagianas (1991).

$\mathrm{DMT}=\mathrm{DM}_{\text {anthesis }}-\left(\mathrm{DM}_{\text {maturity }}-\right.$ grain yield $)$

- Contribution of pre anthesis assimilation to the grain (CPAAG \%): were calculated in applying the following formula mentioned by (Papakosta and Gagianas, 1991). CPAAG\% $=(\mathrm{DM} /$ grain yield $) \times 100$

\section{- Flag Leaf Area (FLA) $\left(\mathbf{c m}^{2}\right)$ :}

When plants reached the maturity stage, plant height $\mathrm{PH}(\mathrm{cm})$ were calculated and then harvested remaining plants from each plot to calculate spike length SL $(\mathrm{cm})$ and yield components [number of spikes $/ \mathrm{m}^{2}(\mathrm{SN})$, number of grains / spike 
(GN) and 1000 grain weight (1000-GW) (g)]. As well as biological yield (BY) (kg / ha, grain yield $(\mathrm{GY})(\mathrm{kg} / \mathrm{ha})$, harvest index $(\mathrm{HI})$ and the measure of productivity score (PS) which is the sum of the components (Biological yield + grain yield + harvest index), which can be relied upon to differentiate between genotypes without resorting to building election indices (Ali, 2004). Data analyzed statistically and Duncan Multiple Range Test was used to determine the significance of the differences between the average traits of genotypes, and the correlation coefficients between traits was estimated to determine the nature of the relationship between studied characters. as well as the analysis of multiple linear regression to demonstrate the effect of each of these characteristics in determining the grain yield.

\section{RESULTS AND DISCUSSION}

Four hybrids and three varieties showed significant differences in all the characters for the analysis of physiological growth. The hybrid $(3 \times 4)$ showed superiority significant on all other genotypes and gave $45.75 \mathrm{~cm}^{2}$ for the FLA, 3.95 for LAI, $0.059 \mathrm{~g} / \mathrm{g} /$ day for RGR, $11.99 \mathrm{mg} / \mathrm{cm}^{2} /$ day for the NAR and $175.8 \mathrm{~g} / \mathrm{ha}$ for DMT, except in CPAAG whereas the hybrid $(1 \times 6)$ gave highest value (Table, 2$)$. The results indicated that the hybrids $(1 \times 6)$ and $(2 \times 3)$ ranked second after $(3 \times 4)$ in all of these characters. On the other hand the genotype $(4 \times 6)$ has lower values in most of the physiological characters. Other researchers have stated that there were differences between varieties of wheat in such characters included in their studies (Al-Rawi and Faisal, 1995 and Aslam Khan et al., 2005).

Results in table (3) show the values of hybrids and varieties for some growth characters, grain yield and its components and productivity score. The significant superiority of the variety Kosem- $\mathrm{N}$ in plant height $(95.5 \mathrm{~cm})$, followed by Acsad65 which reached to $91.0 \mathrm{~cm}$. The hybrid $(3 \times 4)$ showed high significant superiority for the characters, SL, SN/m², GN, $1000-\mathrm{GW}, \mathrm{BY}, \mathrm{GY}, \mathrm{HI}$, and PS gave $7.3 \mathrm{~cm}, 354.8 \mathrm{spike} / \mathrm{m}^{2}, 43.5$ grain/spike, $48.3 \mathrm{~g}, 8717.5 \mathrm{~kg} / \mathrm{ha}, 4292.5 \mathrm{~kg} / \mathrm{ha}$ , $49.3 \%$ and 13059.3 , respectively. It seems clear, the cumulative effect of the superiority of the hybrid $(3 \times 4)$ in many of the characters that have direct relationship to the efficient photosynthesis, such as relative growth rate, net assimilation rate, flag leaf area and dry matter translocation, which have effective role to improving the components of grain yield and grain yield as a final product, these results has been reported by others (Turner, 1997 and Villegas et al., 2001) who found that there was a correlation between high grain yield of wheat and accumulated dry matter in grains during the flowering and grain filling period.

Means in each column followed by the same letter are not significantly different at the 5\% probability.

Simple correlation coefficients between all possible combinations of the fifteen characters are shown in Table (4), in which they can select any of the characters of the high effect or importance on grain yield, also according to these estimates, particularly among the characters that showed positive correlation with the grain yield or components of productivity score (grain yield, biological yield and harvest index) and among these components, which also determined the most important components to be included multiple regression equation, which will be 
Mesopotamia J. of Agric. Vol. (41) No. (1) 2013
ISSN: 2224-9796 (Online)

ISSN: $1815-316 \mathrm{X}$ (Print)

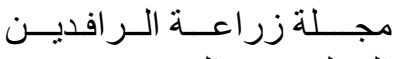

المجلد (41) العدد (1) 2013

adopted as a criterion to differentiate between genotypes. Results indicated that biological yield is positively and significantly correlated with all the characters except with harvest index, which was negative and significant, and this is normal, because it is usually under the water deficit, dependent on rainfall, the increase in vegetative growth may damage the plant from a depletion water prevented a lot of tillers or vegetation growth to give a mature spikes view of the lack of moisture, especially in the grain filling period. Many studiescarried out with modern varieties have reported significant correlations between biological yield and grain yield (Ramos et al., 1985; Turner, 1997; Villegas et al., 2001 and Moragues et al., 2006). Grain yield showed

Table (2): Physiological growth analysis of genotypes.

\begin{tabular}{|c|c|c|c|c|c|c|}
\hline Genotypes & FLA $\left(\mathrm{cm}^{2}\right)$ & LAI & $\begin{array}{c}\text { RGR } \\
(\mathrm{g} / \mathrm{g} / \text { day })\end{array}$ & $\begin{array}{c}\text { NAR } \\
\left(\mathrm{mg} / \mathrm{cm}^{2} / \mathrm{day}\right)\end{array}$ & $\begin{array}{c}\text { DMT } \\
(\mathrm{kg} / \mathrm{ha})\end{array}$ & $\begin{array}{c}\text { CPAAG } \\
(\%)\end{array}$ \\
\hline $1 \times 6$ & $42.00 \mathrm{~b}$ & $3.62 \mathrm{ab}$ & $0.054 \mathrm{~b}$ & $9.95 \mathrm{~b}$ & $170.0 \mathrm{ab}$ & $5.01 \mathrm{a}$ \\
\hline $2 \times 3$ & $41.50 \mathrm{~b}$ & $3.38 \mathrm{bc}$ & $0.057 \mathrm{ab}$ & $11.79 \mathrm{a}$ & $163.3 \mathrm{bc}$ & $4.30 \mathrm{~b}$ \\
\hline $3 \times 4$ & $45.75 \mathrm{a}$ & $3.95 \mathrm{a}$ & $0.059 \mathrm{a}$ & $11.99 \mathrm{a}$ & $175.8 \mathrm{a}$ & $4.43 \mathrm{~b}$ \\
\hline $4 \times 6$ & $28.25 \mathrm{f}$ & $2.23 \mathrm{e}$ & $0.038 \mathrm{e}$ & $6.22 \mathrm{~d}$ & $139.8 \mathrm{f}$ & $4.38 \mathrm{~b}$ \\
\hline Cham- 3 & $31.25 \mathrm{e}$ & $2.33 \mathrm{de}$ & $0.041 \mathrm{~d}$ & $9.23 \mathrm{~b}$ & $145.3 \mathrm{de}$ & $4.56 \mathrm{ab}$ \\
\hline Acsad- 65 & $34.75 \mathrm{~d}$ & $2.63 \mathrm{~d}$ & $0.047 \mathrm{c}$ & $6.40 \mathrm{~d}$ & $160.0 \mathrm{c}$ & $4.83 \mathrm{ab}$ \\
\hline Kosem- N & $38.50 \mathrm{c}$ & $3.20 \mathrm{c}$ & $0.042 \mathrm{~d}$ & $7.95 \mathrm{c}$ & $153.8 \mathrm{~cd}$ & $4.49 \mathrm{~b}$ \\
\hline
\end{tabular}

FLA = Flag leaf area; LAI $=$ Leaf area index; RGR $=$ Relative growth rate; NAR $=$ Net assimilation rate; $\mathrm{DMT}=$ Dry matter translocation; $\mathrm{CPAAG}=$ Contribution of pre anthesis assimilation to the grain.

Means in each column followed by the same letter are not significantly different at the 5\% probability.

Table (3): Yield performance for some growth characters, grain yield, yield components and productivity score of genotypes.

\begin{tabular}{|c|c|c|c|c|c|c|c|c|c|}
\hline Genotypes & $\begin{array}{c}\mathrm{PH} \\
(\mathrm{cm})\end{array}$ & $\begin{array}{c}\mathrm{SL} \\
(\mathrm{cm})\end{array}$ & $\mathrm{SN} / \mathrm{m}^{2}$ & $\mathrm{GN} / \mathrm{S}$ & $\begin{array}{c}1000- \\
\mathrm{GW}(\mathrm{g})\end{array}$ & $\begin{array}{c}\mathrm{BY} \\
(\mathrm{kg} / \mathrm{ha})\end{array}$ & $\begin{array}{c}\mathrm{GY} \\
(\mathrm{kg} / \mathrm{ha})\end{array}$ & $\begin{array}{c}\mathrm{HI} \\
(\%)\end{array}$ & $\mathrm{PS}$ \\
\hline $1 \times 6$ & $88.3 \mathrm{c}$ & $6.0 \mathrm{~b}$ & $335 \mathrm{a}$ & $40.0 \mathrm{bc}$ & $44.0 \mathrm{bc}$ & $8364.0 \mathrm{ab}$ & $3416.8 \mathrm{c}$ & $40.9 \mathrm{c}$ & $11811.7 \mathrm{~b}$ \\
\hline $2 \times 3$ & $85.4 \mathrm{c}$ & $6.4 \mathrm{~b}$ & $365 \mathrm{a}$ & $38.0 \mathrm{c}$ & $42.0 \mathrm{c}$ & $7956.0 \mathrm{ab}$ & $3793.3 \mathrm{~b}$ & $47.7 \mathrm{a}$ & $11672.0 \mathrm{~b}$ \\
\hline $3 \times 4$ & $80.0 \mathrm{e}$ & $7.3 \mathrm{a}$ & $354.8 \mathrm{a}$ & $43.5 \mathrm{a}$ & $48.3 \mathrm{a}$ & $8717.5 \mathrm{a}$ & $4292.5 \mathrm{a}$ & $49.3 \mathrm{a}$ & $13059.3 \mathrm{a}$ \\
\hline $4 \times 6$ & $81.5 \mathrm{e}$ & $5.1 \mathrm{c}$ & $349.8 \mathrm{a}$ & $29.5 \mathrm{~d}$ & $36.8 \mathrm{~d}$ & $7055.5 \mathrm{~cd}$ & $3155.5 \mathrm{c}$ & $44.8 \mathrm{~b}$ & $10255.8 \mathrm{~cd}$ \\
\hline Cham- 3 & $80.0 \mathrm{e}$ & $6.0 \mathrm{~b}$ & $287.0 \mathrm{~b}$ & $39.3 \mathrm{bc}$ & $41.5 \mathrm{c}$ & $6504.5 \mathrm{~d}$ & $3166.0 \mathrm{c}$ & $48.7 \mathrm{a}$ & $9719.3 \mathrm{~d}$ \\
\hline Acsad- 65 & $91.0 \mathrm{~b}$ & $6.3 \mathrm{~b}$ & $265.3 \mathrm{~b}$ & $40.3 \mathrm{bc}$ & $41.5 \mathrm{c}$ & $7642.5 \mathrm{bc}$ & $3315.3 \mathrm{~d}$ & $43.4 \mathrm{~b}$ & $11001.2 \mathrm{bc}$ \\
\hline Kosem- N & $95.5 \mathrm{a}$ & $7.0 \mathrm{a}$ & $342.0 \mathrm{a}$ & $41.0 \mathrm{ab}$ & $45.8 \mathrm{ab}$ & $7052.8 \mathrm{~cd}$ & $3429.0 \mathrm{~d}$ & $48.6 \mathrm{a}$ & $10530.3 \mathrm{~cd}$ \\
\hline
\end{tabular}


$\mathrm{PH}=$ Plant height; $\mathrm{SL}=$ Spike length; $\mathrm{SN} / \mathrm{m}^{2}=$ Spike number $/ \mathrm{m}^{2} ; \mathrm{GN} / \mathrm{S}=$ Grain number/ spike; 1000-GW=1000-grain weight; $\mathrm{BY}=$ Biological yield; GY= Grain yield; $\mathrm{HI}=$ Harvest index; PS= Productivity score.

positive and significant correlation with most of the characters except with CPAAG and plant height and positive but not significant with harvest index. With regard to correlation between productivity score components, it is noted as positive with the exception of the negative correlation between biological yield and harvest index. Therefore, Thomas and Tapsell (1985) reported that the effectiveness of the selection depend on the knowledge of the correlation between the selected characters showing the importance and usefulness of the positive correlation between some of the characters in improving the one due to other. Hence the important of positive correlation between grain yield and its components (the number of spikes $/ \mathrm{m}^{2}$, the number of grains / spike and 1000 grain weight), these results are in agreement with the findings (Ozkan et al., 1997 and Ali, 2002). The positive and significant correlations between the characteristics of physiological growth analysis (LAI, FLA, RGR, NAR and DMT) as well as they correlated positive with grain yield, productivity score and biological yield.

The analysis of regression variance (Table, 5) showed high significant effects of the variance ratio which is interpreted by the independent variables of the variation of the dependent variable. From the results of this analysis, which presented in Table (6) and based on the values of statistical t test and significance level special for (Beta) value in the last two columns where the value of (Sig.) interview any of the (Beta) values is less than 0.05 , this means that the character corresponding of these valueshave an effect statistically significant, it is clear that the estimated relative to the independent variables in predicting the values of the dependent variable identified by $(85 \%)$.

Table (4): Correlation coefficients between studied characters.

\begin{tabular}{|l|c|c|c|c|c|c|c|c|c|c|c|c|c|c|}
\hline & FLA & LAI & RGR & NAR & DMT & CPAAG & PH & SL & SN/M & GN/S & $\begin{array}{c}1000- \\
\text { GW }\end{array}$ & GY & BY & HI \\
\hline PS & $0.72^{*}$ & $0.67^{*}$ & $0.79^{*}$ & $0.57^{*}$ & $0.89^{*}$ & -0.19 & -0.19 & $0.51^{*}$ & $0.46^{*}$ & $0.47^{*}$ & $0.59^{*}$ & $0.90^{*}$ & $0.98^{*}$ & -0.08 \\
\hline HI & 0.14 & 0.14 & -0.03 & 0.29 & -0.13 & $-0.49^{*}$ & -0.22 & $0.44^{*}$ & -0.08 & 0.21 & 0.23 & 0.36 & $-0.28^{*}$ & \\
\hline BY & $0.68^{*}$ & $0.62^{*}$ & $0.78^{*}$ & $0.51^{*}$ & $0.89^{*}$ & -0.09 & -0.05 & 0.39 & $0.44^{*}$ & $0.41^{*}$ & $0.53^{*}$ & $0.79^{*}$ & & \\
\hline GY & $0.75^{*}$ & $0.69^{*}$ & $0.74^{*}$ & $0.67^{*}$ & $0.77^{*}$ & -0.39 & -0.19 & $0.66^{*}$ & $0.41^{*}$ & $0.52^{*}$ & $0.64^{*}$ & & & \\
\hline $\begin{array}{l}1000- \\
\text { GW }\end{array}$ & $0.72^{*}$ & $0.61^{*}$ & $0.54^{*}$ & $0.52^{*}$ & $0.67^{*}$ & 0.01 & 0.16 & $0.78^{*}$ & 0.01 & $0.78^{*}$ & & & & \\
\hline GN/S & $0.67^{*}$ & $0.57^{*}$ & $0.52^{*}$ & $0.47^{*}$ & $0.66^{*}$ & 0.07 & 0.27 & $0.78^{*}$ & 0.03 & & & & & \\
\hline SN/M & 0.27 & 0.29 & 0.29 & -0.05 & 0.31 & -0.25 & 0.27 & 0.22 & & & & & & \\
\hline SL & $0.49^{*}$ & $0.62^{*}$ & $0.49^{*}$ & $0.46^{*}$ & $0.58^{*}$ & -0.07 & 0.27 & & & & & & & \\
\hline PH & 0.14 & 0.14 & -0.12 & -0.35 & 0.09 & 0.24 & & & & & & & & \\
\hline CPAAG & -0.01 & 0.12 & 0.10 & -0.13 & 0.09 & & & & & & & & & \\
\hline DMT & $0.80^{*}$ & $0.79 *$ & $0.85^{*}$ & $0.60^{*}$ & & & & & & & & & & \\
\hline NAR & $0.76^{*}$ & $0.69 *$ & $0.80^{*}$ & & & & & & & & & & & \\
\hline RGR & $0.84^{*}$ & $0.79 *$ & & & & & & & & & & & & \\
\hline LAI & $0.92^{*}$ & & & & & & & & & & & & & \\
\hline
\end{tabular}

FLA = Flag leaf area; LAI $=$ Leaf area index; RGR $=$ Relative growth rate; NAR $=$ Net assimilation rate; $\mathrm{DMT}=$ Dry matter translocation; $\mathrm{CPAAG}=$ Contribution of pre anthesis assimilation to the 
grain; $\mathrm{PH}=$ Plant height; $\mathrm{SL}=$ Spike length; $\mathrm{SN} / \mathrm{m}^{2}=$ Spike number $/ \mathrm{m}^{2} ; \mathrm{GN} / \mathrm{S}=$ Grain number/ spike; 1000-GW= 1000-grain weight; $\mathrm{BY}=$ Biological yield; GY= Grain yield; $\mathrm{HI}=$ Harvest index; $\mathrm{PS}=$ Productivity score.

We can also identify any variables that have a greater effect on grain yield through the values of transaction characters (Beta) corresponding to each of them (where weights Beta regression coefficients record standardized coefficients or direct effects as known path coefficients). The biological yield showed highest direct effect on grain yield (0.694) because the value of (Beta) corresponding is the largest,

Table (5): Analysis of regression variance for dependent variable (grain yield) on tencharacters as (independent variables).

\begin{tabular}{|c|c|c|c|}
\hline SOV & df & Ms & Cal. F. \\
\hline Regression & 10 & 402976.678 & $9.694^{* *}$ \\
\hline Residual & 17 & 41568.734 & \\
\hline Total & 27 & & \\
\hline
\end{tabular}

followed by net assimilation rate (NAR), and spike length (SL), while the effect of $\mathrm{SN} / \mathrm{m}^{2}$ is positive but has not reached the significant level. These results are in consonance with results of Moragues et al. (2006), who reported highly significant positive association between biological yield and grain yield, in addition, the stepwise regression analyses performed to identify the biological traits that better explained variations in grain yield, which explained $72 \%$ of yield variations. Thus, the regression predict equation as follows: $\mathrm{Y}(\mathrm{GY})=-242.515(\mathrm{BY})-6.945$ (DMT) - 14.96 (FLA) - $6861.525($ RGR) + 85.167 (LAI) + 80.54 (NAR) + 230.159 (SL) + $10.42(1000 \mathrm{GW})-7.784(\mathrm{GN})+1.762\left(\mathrm{SN} / \mathrm{m}^{2}\right)$. Based on this equation and give importance to the attributes of the BY, NAR and SL addition to taking the values of productivity score and grain yield of genotypes into account, we can select the hybrid (Acsad- $65 \times$ Kosem- N) which was superior in all these criteria to continue its breeding using bulk method in a view to adopting a new variety of durum wheat suitable for rainfall conditions

Table (6): Results of multiple linear regression analysis between 10 characters and grain yield.

\begin{tabular}{|l|c|c|c|c|c|c|}
\hline Variables & \multicolumn{2}{|c|}{$\begin{array}{c}\text { Un standardized } \\
\text { Coefficients }\end{array}$} & $\begin{array}{c}\text { Standardized } \\
\text { Coefficients }\end{array}$ & T & Sig. & r xy \\
\hline & B & Std. Error & Beta & & & \\
\hline (Constant) & -242.515 & 891.831 & & -0.272 & 0.789 & \\
\hline BY & 0.3350 & 0.145 & 0.694 & 2.308 & $0.034^{*}$ & $0.79^{*}$ \\
\hline DMT & -6.945 & 12.454 & -0.223 & -0.558 & 0.584 & $0.77^{*}$ \\
\hline FLA & -14.960 & 25.781 & -0.216 & -0.580 & 0.569 & $0.75^{*}$ \\
\hline RGR & -6861.525 & 14143.227 & -0.135 & -0.485 & 0.634 & $0.74^{*}$ \\
\hline LAI & 85.167 & 192.097 & 0.135 & 0.443 & 0.663 & $0.69^{*}$ \\
\hline NAR & 80.540 & 36.389 & 0.439 & 2.213 & $0.041^{*}$ & $0.67^{*}$ \\
\hline
\end{tabular}


Mesopotamia J. of Agric.

Vol. (41) No. (1) 2013
ISSN: 2224-9796 (Online) ISSN: $1815-316 \mathrm{X}$ (Print)
مجـــلـة زر اعـــة الـر افديــن

المجلد (41) العدد (1) 2013

\begin{tabular}{|l|c|c|c|c|c|c|}
\hline SL & 230.159 & 110.305 & 0.403 & 2.087 & $0.042^{*}$ & $0.66^{*}$ \\
\hline $1000-\mathrm{GW}$ & 10.420 & 23.167 & 0.095 & 0.450 & 0.659 & $0.64^{*}$ \\
\hline $\mathrm{GN} / \mathrm{S}$ & -7.784 & 19.750 & -0.083 & -0.394 & 0.698 & $0.52^{*}$ \\
\hline $\mathrm{SN} / \mathrm{m}^{2}$ & 1.762 & 1.665 & 0.151 & 1.058 & 0.305 & $0.41^{*}$ \\
\hline \multicolumn{7}{|r|}{} \\
\hline
\end{tabular}

\title{
الأداء الحقلي والنمو الفسيولوجي لأربعة هجن مستتبطة

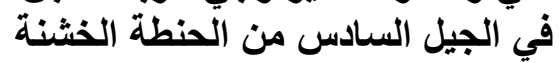

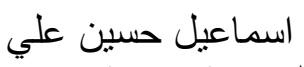 \\ كلية الزر اعة/جامعة صلاحِ الدين
}

E-mail:dr.ismail@ymail.com

\begin{abstract}
الخلاصة
نفذت الدراسة في حقل كلية الزر اعة بجامعة صلاح الدين في أربيل خلال الموسم

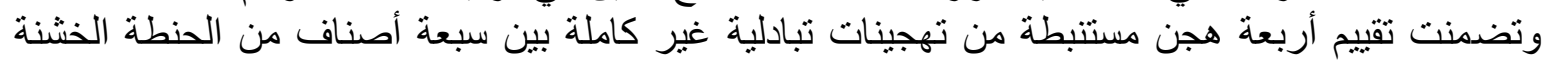

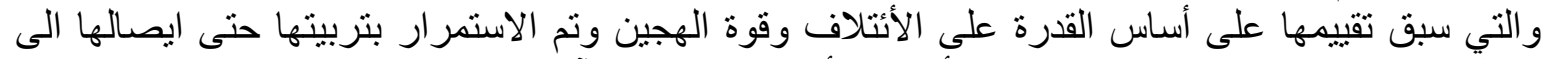

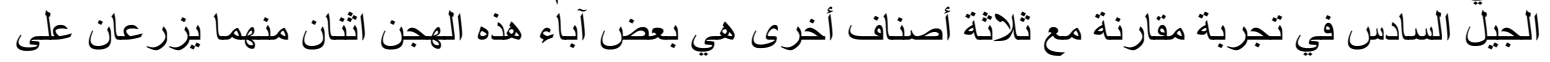

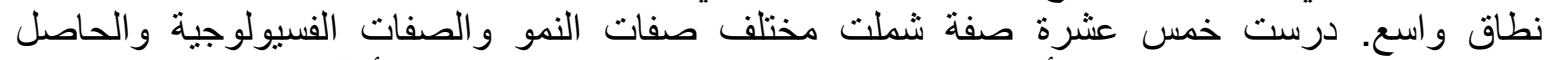

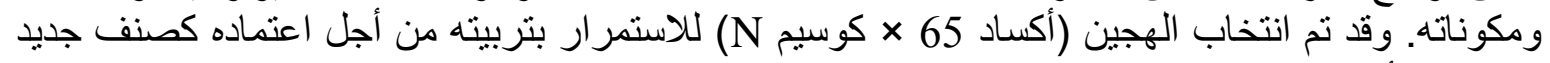

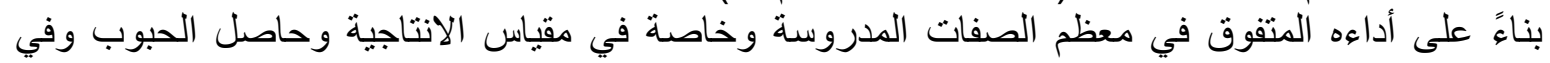

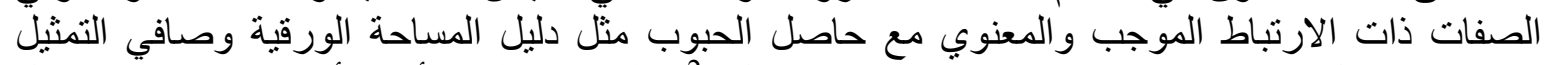

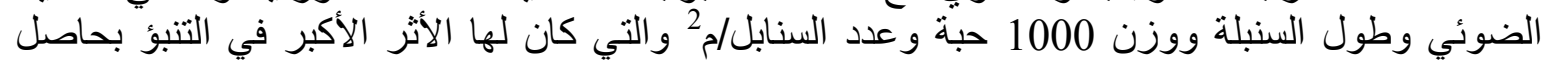
الحبوب حسب نتائج تحليل الانحدار المتعدد.
\end{abstract}

تاريخ تسلم البحث 2012/1/29 2011 وقبوله

\section{REFERENCES}

Abayomi, Y., and D. Wright (1999). Effects of water stress on growth and yield of spring wheat (Triticum aestivum L.) cultivars. Tropical Agriculture, 76: 120125.

Abd-El-Gawad, A. A., A. M. Badr, N. A. Nour El-Din and R. I. El-Sayed (1985). Comparative studies of Giza 155 and Mexipac cultivars of wheat. Effect of nitrogen on growth and yield. Annals of Agriculture Science, 3:3-12.

Ali, I. H. (2002). Estimation of genetic parameters for yield and its components in wheat (Triticum spp.). Sulaimani Zanco Journal, 5(2):2-8.

Ali, I. H. (2004). Productivity score and selection index in wheat. Zanco Journal, 16(4):7-12.

Ali, I. H. (2006). Genetic Analysis of Diallel Crosses for $F_{1}$ and $F_{2}$ Generations and Selection in Durum Wheat. Ph. D. Thesis, College of Agriculture, Salahaddin University. 
Ali, I. H. and N. B. Ismail (2005). Determination optimum characters for breeding wheat and screening 20 varieties for drought resistance. Zanco Journal, 17(2): 9-23.

Al-Rawi, I. M. and M. S. Faisal (1995). Growth analysis of four wheat cultivars under two seeding rates and rain fed conditions. Mesopotamia Journal of Agriculture. 27: 106-111.

Aslam Khan, M., M. Abid, N. Hussain and T. Imran (2005). Growth analysis of wheat (Triticum aestivum L.) cultivars under saline conditions. International Journal of Agriculture Biology, 7(3):508- 510.

Campbell, C. A.; W. L. Pelton and K. F. Nielsen (1969). Influence of solar radiation and soil moisture on growth and yield of Chinook wheat. Canadian Journal Plant Science, 70:1641-1646.

Garretsen, F. and M. Keuls (1986). Functions of time for growth characters, their evaluation and approximation to examine differences between genotypes. Euphytica, 35:11-15.

Hafid, R. E., D. H. Smith, M. Karrou and K. Samir (1998). Morphological attributes associated with early-season drought tolerance in spring durum wheat in a Mediterranean environment. Euphytica, 101: 273-282.

Hay, R. K. M., and A. J., Walker (1989). An Introduction To The Physiology Of Crop Yield. Longman Scientific and Technical, Harlow.

Hunt, R. (1982). Plant Growth Curves the Functional Approach to Plant Growth Analysis. Edward Arnold, London, UK.

Langer, R. H. M. (1967). Physiological approaches to yield determination in wheat and barley. Field Crops Abstracts, 20:101-106.

Moragues, M., L. F. Garc1'a del Moral, M. Moralejo and C. Royo (2006). Yield formation strategies of durum wheat landraces with distinct pattern of dispersal within the Mediterranean basin II. Biomass production and allocation. Field Crops Research, 95: 182-193.

Ozkan, H., T. Yagbasanlar and I. Genc (1997). Genetic analysis of yield components, harvest index and biological yield in bread wheat under Mediterranean climatic conditions. Rachis, 49-52.

Papakosta, D. K. and A. A. Gagianas (1991). Nitrogen and dry matter accumulation, remobilization, and losses for Mediterranean wheat during grain filling. Agronomy Journal, 83: 864-870.

Poehlman, J. M. and D. A. Steper (1994). Breeding Field Crops. 4th ed. Iowa State University Press Ames, U. S. A.

Ramos, J. M., Garci'a del Moral, L. F., and L. Recalde (1985). Vegetative growth of winter barley in relation to environmental conditions and grain yield.

Journal Agriculture Science, 104: 413-419.

Simane, B., J. M. Peacock and P. C. Struik (1993). Differences in developmental plasticity and growth rate among drought-resistant and susceptible cultivars of durum wheat (Triticum turgidum L. var. durum). Plant and Soil, 157: 155166.

Spitters, C. J. T.and T. Kramer. 1986. Differences between spring wheat cultivars in early growth. Euphytica, 35:273-292. 
Thomas, H. (1975). The growth response to weather of simulated vegetative swards of a single genotype of lolium perenne. Journal Agriculture Science, 84:333343.

Thomas, W. T. B. and C. R. Tapsell (1985). Cross prediction studies on spring barley.3.Correlations between characters. Theoretical Applied Genetic., 71:550-555.

Turner, N. C. (1997). Further progress in crop water relations. Advances In Agronomy, 58: 293-338.

Villegas, D., N. Aparicio, R. Blanco and C. Royo (2001). Biomass accumulation and main stem elongation of durum wheat grown under Mediterranean conditions. Annals of Botany, 88: 617-627.

Watson, D. J., J. N. Thorne and S. A. W. French. (1963). Analysis of growth and yield of winter and spring wheat. Annals of Botany, 27:1-22. 